\title{
Aanscherping van rechtsbescherming en handhaving in milieuzaken: het recht op schone lucht
}

\author{
Mr. dr. F.M. Fleurke*
}

In twee hier te bespreken arresten bouwt het Hof van Justitie voort op de rechtspraak met betrekking tot het recht op schone lucht zoals neergelegd in Richtlijn 2008/50/EG betreffende de luchtkwaliteit en schonere lucht voor Europa.

De belangrijkste aanvulling die het Hof van Justitie in het Craeynest-arrest geeft, is dat ook de wetenschappelijke beoordeling van de luchtkwaliteit door het bepalen van de plaats van een bemonsteringspunt onderworpen kan worden aan rechterlijke toetsing om zodoende het nuttig effect van de richtlijn te garanderen.

Het tweede arrest, Deutsche Ummelthilfe, is opzienbarend omdat het Hof van Justitie hierin oordeelde dat het EU-recht onder bepaalde voorwaarden een nationale rechter als ultimum remedium de verplichting geeft gebruik te maken van een nationale bevoegdheid lijfsdwang op te leggen aan het bevoegd gezag als dit stelselmatig weigert milieumaatregelen te nemen in het kader van Richtlijn 2008/50/EG en als niet aannemelijk is dat dit zal veranderen.

Hoewel gewezen in de context van luchtkwaliteit hebben beide arresten ook implicaties voor andere gebieden uit het milieurecht, zoals biodiversiteit, klimaat en waterkwaliteit.

Hvf 26 juni 2019, zaak C-723/17, ECLI:EU:C: 2019:533 (Lies Craeynest e.a./Brussels Hoofdstedelijk Gemest en Brussels Instituut voor Milieubeheer)

Hv7 19 december 2019, zaak C-752/18, ECLI:EU:C: 2019:1114 (Deutsche Ummelthilfe eV/Freistaat Bayern)

* Mr. dr. F.M. (Floor) Fleurke is als universitair hoofddocent Europees milieurecht verbonden aan de Universiteit van Tilburg.

\section{Inleiding}

Het afgelopen jaar kenmerkt zich door een serie opmerkelijke rechterlijke uitspraken over luchtkwaliteit en klimaat. De Hoge Raad hield de Urgenda-zaak overeind, en daarvoor zette de Afdeling bestuursrecht van de Raad van State het mes in de Programmatische Aanpak Stikstof. Nu de druk op milieu en klimaat toeneemt, lijkt de rol van de rechter in milieuzaken aldus steeds prominenter te worden; op EU-niveau heeft het Hof van Justitie deze rol traditioneel al op zich genomen. ${ }^{1}$

In de twee arresten die in deze bijdrage zullen worden besproken geeft het Hof van Justitie de nationale rechter nog meer armslag om een prominente rol in de rechtsbescherming en handhaving van milieuzaken te vervullen. Beide arresten gaan over luchtkwaliteit en hebben Richtlijn 2008/50/EG betreffende de luchtkwaliteit en schonere lucht voor Europa als onderwerp. ${ }^{2}$

Luchtvervuiling is in heel Europa een groot probleem en levert jaarlijks een groot aantal slachtoffers op. ${ }^{3}$ Sinds de jaren tachtig heeft de EU daarom richtlijnen angenomen met de doelstelling de luchtkwaliteit via grenswaarden en drempelwaarden te verbeteren. Voor een groot deel is dit gelukt: het Rijksinstituut voor Volksgezondheid en Milieu (RIVM) berekende dat de Nederlander gemiddeld zes jaar langer leeft dankzij de Europese luchtkwaliteitsrichtlijnen. Ondanks deze verbetering blijft de luchtkwaliteit nog veelal beneden de gestelde normen uit Richtlijn 2008/50/EG. Vanwege directe gezondheidseffecten én de ontwikkeling van vrij eenvoudige en toegankelijke meettechnologieën zijn

1. Zie bijvoorbeeld F. Jacobs, 'The Role of the European Court of Justice in the Protection of the Environment', Journal of Environmental Law 2006, nr. 2, p. 185-205.

2. Richtlijn 2008/50/EG van het Europees Parlement en de Raad van 20 mei 2008 betreffende de luchtkwaliteit en schonere lucht voor Europa, PbEU 2008, L 152/1-44.

3. European Environment Agency, 'Air Quality in Europe' (Report No 10/2019 2019). 
steeds meer burgers en ngo's in verschillende lidstaten waaronder Nederland naar de rechter gestapt om de gestelde Europese grenswaarden af te dwingen. ${ }^{4}$ In eerdere rechtspraak van het Hof van Justitie is hiervoor al de weg geplaveid: daar waar grenswaarden worden overschreden hebben particulieren het recht om naar de nationale rechter te gaan en verbetering door middel van luchtkwaliteitsplannen af te dwingen. ${ }^{5}$

De twee arresten bouwen voort op deze lijn in de jurisprudentie en breiden zoals hieronder zal worden besproken de rechtsbescherming en handhavingsmogelijkheden verder uit. In het Craeynest-arrest ging het om de plaatsing van meetapparatuur voor het beoordelen en monitoren van de luchtkwaliteit. ${ }^{6}$ In het Deutsche Ummelthilfe-arrest ging het om de vraag welke middelen tot het arsenaal van de nationale rechter behoren om naleving van Richtlijn 2008/50/EG af te dwingen als vaststaat dat de lidstaat of een deel ervan in gebreke blijft en geen gehoor geeft aan rechterlijke beslissingen die hem op straffe van dwangsommen bevelen milieumaatregelen te nemen, en waarvan niet aannemelijk is dat dit zal veranderen. ${ }^{7}$ Kan een nationale rechter dan als ultimum remedium lijfsdwang opleggen aan dragers van het bevoegde gezag?

Beide arresten maken duidelijk dat de normen uit Richtlijn 2008/50/EG nageleefd moeten worden door het bevoegde gezag. In dit artikel worden deze arresten geplaatst in het leerstuk van de procedurele autonomie. Hiertoe zal eerst het juridisch kader van Richtlijn 2008/50/EG beknopt uiteengezet worden. Vervolgens zal ik beide arresten bespreken en van commentaar voorzien. Specifiek zal worden ingegaan op de ontwikkeling van een recht op schone lucht en op de versterkte rol van de rechter bij het beoordelen van wetenschappelijke en technische gegevens. Hoewel het recht op schone lucht niet als zodanig is opgenomen in de richtlijn heeft het Hof van Justitie de bestaande lijn in de jurisprudentie verder ontwikkeld door het verband tussen de luchtkwaliteitsrichtlijn en menselijke gezondheid te benadrukken. $^{8}$

4. Voor een overzicht van rechtspraak over luchtkwaliteit en de implementatie van Richtlijn 2008/50/EG, zie www.right-to-clean-air.eu/en/. Zie ook het rapport van European Court of Auditors, 'Our Health Still Insufficiently Protected', 2018, www.eca.europa.eu/Lists/ECADocuments/ SR18_23/SR_AIR_QUALITY_EN.pdf.

5. HvJ 25 juli 2008, zaak C-237/07, ECLI:EU:C:2008:447 (Janecek/Freistaat Bayern); HvJ 28 november 2013, zaak C-404/13, ECLI:EU:C: 2014:2382 (ClientEarth/The Secretary of State for the Environment, Food and Rural Affairs).

6. HvJ 26 juni 2019, zaak C-723/17, ECLI:EU:C:2019:533 (Lies Craeynest e.a./Brussels Hoofdstedelijk Gewest en Brussels Instituut voor Milieubeheer).

7. HvJ 19 december 2019, zaak C-752/18, ECLI:EU:C:2019:1114 (Deutsche Umwelthilfe eV/Freistaat Bayern).

8. Zie hierover eveneens D. Misonne, 'The emergence of a right to clean air: Transforming European Union law through litigation and citizen science', RECIEL 6 mei 2020, p. 1-12.

\section{De Luchtkwaliteitsrichtlijn}

Richtlijn 2008/50/EG is het centrale instrument om luchtvervuiling in Europa terug te dringen. Deze richtlijn brengt eerdere Europese richtlijnen die sinds de jaren tachtig tot stand zijn gebracht, in één richtlijn samen.

Volgens artikel 4 wijzen lidstaten voor hun hele grondgebied zones en agglomeraties aan waarin luchtkwaliteitsbeoordeling en luchtkwaliteitsbeheer plaatsvinden. Artikel 13 vormt de kern van de richtlijn en bepaalt de grenswaarden en alarmdrempels voor de bescherming van de menselijke gezondheid. Lidstaten dienen ervoor te zorgen dat de niveaus van verontreinigde stoffen in de lucht zoals stikstofdioxide en fijnstof vastgestelde grenswaarden niet overschrijden. ${ }^{9}$

Artikel 23 lid 1 verplicht vervolgens om luchtkwaliteitsplannen vast te stellen wanneer het niveau van verontreinigende stoffen in de lucht in bepaalde zones of agglomeraties een grenswaarde of streefwaarde overschrijdt (inclusief overschrijdingsmarge), om de bepaalde grenswaarde of streefwaarde te bereiken. ${ }^{10}$ De richtlijn bevat tal van bepalingen die voorschrijven hoe luchtkwaliteit beoordeeld dient te worden. Artikel 6 en 7 zijn in dit kader relevant; artikel 6 schrijft de beoordelingscriteria voor terwijl artikel 7 gaat over de bemonsteringspunten en bepaalt dat de plaats van de bemonsteringspunten voor de meting van o.a. stikstofdioxide en stikstofoxiden in de lucht wordt bepaald overeenkomstig de in bijlage III genoemde criteria. In deze bijlage staat dat de bemonsteringspunten zich op een zodanige plaats dienen te bevinden dat gegevens worden verkregen over

'de gebieden binnen zones en agglomeraties waar de hoogste concentraties voorkomen waaraan de bevolking rechtstreeks of onrechtstreeks kan worden blootgesteld gedurende een periode die in vergelijking met de middelingstijd van de grenswaarde(n) niet verwaarloosbaar is'. ${ }^{11}$

Als de bemonsteringpunten zijn vastgesteld zijn er ook nog criteria opgenomen voor de exacte locatie van de bemonsteringspunten op microschaal, zoals de afstand tussen de bemonsteringsbuis en de bodem, de plaatsing ervan ten opzichte van straten en kruispunten alsmede andere technische vereisten. ${ }^{12}$

De procedures voor de keuze van de locaties moeten bovendien volledig worden gedocumenteerd met behulp van bijvoorbeeld foto's in verschillende windrichtingen van de omgeving en een gedetailleerde kaart. De locaties moeten geregeld worden geëvalueerd, waarbij opnieuw

9. Zie Bijlage $\mathrm{XI}$ en Bijlage IX. De termijn voor het bereiken van de grenswaarden is gesteld op 1 januari 2005 voor PM10, 1 januari 2010 voor NO2, en 1 januari 2015 voor PM2.5

10. In Nederland vormen de overschrijdingen van de grenswaarden van stikstofdioxide (NO2) en fijnstof (PM10, PM2.5) de grootste problemen

11. Richtlijn 2008/50/EG, Bijlage III, onder B, a).

12. Richtlijn 2008/50/EG, Bijlage III, onder C. 
documentatie moet worden aangelegd om te garanderen dat te allen tijde aan de selectiecriteria wordt voldaan. ${ }^{13}$

\section{Zaak Craeynest}

Feitelijke achtergrond en prejudiciële vragen Het verzoek om een prejudiciële beslissing was ingediend in een geding tussen vier inwoners van het Brusselse Hoofdstedelijke Gewest (België) die bezorgd zijn om de luchtkwaliteit in hun leefomgeving, en de non-gouvernementele organisatie (ngo) Client Earth, die de bescherming van het leefmilieu tot doel heeft, tegen het Brusselse Hoofdstedelijke Gewest en het Brusselse Instituut voor Milieubeheer.

Verzoekers hebben de rechter verzocht vast te stellen dat de richtlijn niet is nageleefd en het Brusselse Hoofdstedelijke Gewest te bevelen bemonsteringspunten te installeren op de gepaste locaties, zoals in een specifieke straat of op een specifiek kruispunt.

De eerste prejudiciële vraag - waaraan ik in dit artikel de meeste aandacht zal besteden - betreft de rol van de nationale rechter: Behoort het aan de nationale rechter om op vordering van particulieren die rechtstreeks getroffen worden door de overschrijding van de grenswaarden van de luchtkwaliteit te onderzoeken of de bemonsteringspunten geplaatst werden overeenkomstig de in de richtlijn gestelde criteria, en zo neen, jegens de nationale autoriteit alle noodzakelijke maatregelen te treffen, zoals een bevel, zodat de bemonsteringspunten geplaatst zouden worden overeenkomstig die criteria?

De tweede vraag gaat over de vaststelling van een overschrijding van een grenswaarde in de zin van artikel 13 lid 1 en artikel 23 lid 1 Richtlijn 2008/50/EG. Het stond in casu vast dat de gestelde grenswaarde van 40 $\mu \mathrm{g} / \mathrm{m}^{3}$ stikstofdioxide op verschillende bemonsteringspunten werd overschreden. De concentratie stikstofdioxide bleef weliswaar lager dan het jaarlijkse gemiddelde van $40 \mu \mathrm{g} / \mathrm{m}^{3}$ op basis van het gemiddelde van de meetresultaten van alle bemonsteringspunten die zich daar bevinden, maar verzoekers zijn van mening dat volgens de bewoordingen van artikel 13 lid 1 Richtlijn 2008/50/EG ('in de gehele zones en agglomeraties') de grenswaarden op geen enkele locatie binnen een zone mogen worden overschreden. Het Brusselse Hoofdstedelijke Gewest en het Brusselse Instituut voor Milieubeheer menen daarentegen dat de luchtkwaliteit in haar geheel dient te worden beoordeeld voor een zone of agglomeratie.

De vraag is of er sprake is van een overschrijding wanneer deze wordt vastgesteld op grond van de meetresultaten van één bemonsteringspunt in de zin van artikel 7 van deze richtlijn, of pas wanneer deze blijkt uit het gemiddelde van de meetresultaten van alle bemonsteringspunten in een bepaalde zone.
Oordeel van het Hof van Justitie in Craeynest Het Hof van Justitie begint met het in herinnering brengen dat de dwingende werking van artikel 288 Verdrag betreffende de werking van de Europese Unie (VWEU) met zich meebrengt dat de daarbij opgelegde verplichtingen moeten kunnen worden ingeroepen, 'met name voor een richtlijn waarvan het doel is gelegen in de beheersing en vermindering van de luchtverontreiniging, en die derhalve strekt ter bescherming van de volksgezondheid'. ${ }^{14}$ Justitiabelen moeten dus in beginsel toegang tot de rechter hebben zodat nagegaan kan worden of het bevoegde gezag binnen de door de richtlijn aangegeven beoordelingsgrenzen is gebleven. ${ }^{15}$

Het Hof van Justitie gaat vervolgens in op de gedetailleerde regels voor het gebruik en de plaatsing van de bemonsteringspunten voor de meting van de luchtkwaliteit in de zones en agglomeraties. Het bespreekt artikel 6 en 7 van de richtlijn en de criteria uit bijlage III, en stelt vast dat de bemonsteringspunten gegevens moeten verschaffen die representatief zijn voor de locaties in een zone of agglomeratie die worden gekenmerkt door een bepaald niveau van verontreiniging. Het komt tot de slotsom dat Richtlijn 2008/50/EG voorziet in duidelijke, nauwkeurige en onvoorwaardelijke verplichtingen, zodat particulieren zich daarop kunnen beroepen jegens de Staat. ${ }^{16}$ Dat geldt in casu voor de verplichting om bemonsteringspunten op een zodanige plaats te installeren dat gegevens worden verkregen over de verontreiniging op de meest vervuilde plaatsen. Dit geldt ook voor de verplichting om ten minste het bepaalde minimumaantal bemonsteringspunten te plaatsen. ${ }^{17}$

Het Hof van Justitie wijst erop dat de plaatsing van de bemonsteringspunten een cruciale rol speelt voor beoordeling en verbetering van de luchtkwaliteit. ${ }^{18}$ De bemonsteringspunten zijn dus allerminst slechts een technisch detail maar het voornaamste instrument voor de beoordeling van de luchtkwaliteit zodat de beleidsvrijheid beperkt is. Daarbij benadrukt het Hof van Justitie dat beslissingen op betrouwbare wetenschappelijke gegevens moeten zijn gebaseerd waarbij wordt aangegeven op basis van welke elementen de keuze van de plaatsing van alle locaties voor controle van de luchtkwaliteit is gemaakt. ${ }^{19}$ Deze documentatie moet geregeld worden bijgewerkt om te garanderen dat nog steeds aan de selectiecriteria wordt voldaan. ${ }^{20}$ De nationale rechter is dan ook bevoegd - volgens zijn eigen procesregels - om de betrokken nationale autoriteit te bevelen alle noodzakelijke maatregelen te treffen om ervoor te zorgen dat de plaatsing van deze punten voldoet aan de in deze richtlijn vastgestelde criteria. ${ }^{21}$

14. Richtlijn 2008/50/EG, Bijlage III, onder D. Zie ook Janecek, punt 37 en Client Earth, punt 55.

15. Craeynest, punt 34; zie ook HvJ 24 oktober 1996, zaak C-72/95, ECLI:EU:C:1996:404 (Kraaijeveld e.a.), punt 56.

16. Craeynest, punt 42 .

17. Craeynest, punt 43 .

18. Craeynest, punt 47.

19. Craeynest, punt 51. Zie ook Richtlijn 2008/50, bijlage III, deel D.

20. Craeynest, punt 52.

21. Craeynest, punt 53. Zie ook Janecek, punt 38 en 39 en ClientEarth, punt 55,56 en 58 . 
De tweede vraag ziet erop welk meetresultaat in acht moet worden genomen bij de vaststelling of de grenswaarden zijn overschreden. Het Hof van Justitie oordeelt dat de richtlijn beoogt de menselijke gezondheid te beschermen en voorziet daartoe in maatregelen ter bestrijding van de uitstoot van verontreinigende stoffen bij de bron. Daarom dient de daadwerkelijke luchtverontreiniging te worden bepaald waaraan de bevolking of een deel daarvan wordt blootgesteld, en dient te worden gewaarborgd dat passende maatregelen worden getroffen om de bronnen van deze verontreiniging te bestrijden. ${ }^{22}$ Hieruit volgt dat de bepaling van het gemiddelde van de meetresultaten van alle bemonsteringspunten in een zone of agglomeratie geen nuttige aanwijzingen verschaft over de blootstelling van de bevolking aan verontreinigende stoffen. ${ }^{23}$ Het is dan ook voldoende dat een grenswaarde op één enkel bemonsteringspunt wordt overschreden opdat de verplichting ontstaat tot vaststelling van een luchtkwaliteitsplan overeenkomstig artikel 23 lid 1 Richtlijn 2008/50/EG. ${ }^{24}$

\section{Zaak Deutsche Umwelthilfe}

Feitelijke achtergrond en prejudiciële vragen

Ook in deze zaak ging om een geding tussen een ngo voor de bescherming van het milieu, namelijk Deutsche Umwelthilfe tegen de deelstaat Beieren te Duitsland. In casu staat vast dat de grenswaarde voor stikstofdioxide (NO2), namelijk $40 \mu \mathrm{g} / \mathrm{m}^{3}$ over een kalenderjaar, op talrijke plaatsen in de stad München (Duitsland) op meerdere kilometers van het wegennet - soms fors - is overschreden.

Nadat Deutsche Umwelthilfe beroep had ingesteld bij de bestuursrechter in eerste aanleg in München, heeft deze rechter de Freistaat Bayern bij vonnis van 9 oktober 2012 gelast een actieplan voor de luchtkwaliteit van de stad München conform artikel 23 Richtlijn 2008/50/EG te maken met maatregelen om de vastgestelde grenswaarde voor stikstofdioxide in deze stad zo snel mogelijk te behalen. $\mathrm{Na}$ verschillende procedures heeft de hoogste bestuursrechter van de deelstaat Beieren bij beschikking van 27 februari 2017 de Freistaat Bayern een dwangsom van 2000 tot 4000 euro opgelegd als hij niet de nodige maatregelen zou nemen, waaronder de oplegging van rijverboden voor bepaalde voertuigen met dieselmotor in verschillende delen van de stad. Na niet-nakoming hiervan is bij beschikking van 26 oktober 2017 een dwangsom van 4000 euro opgelegd. De Freistaat Bayern heeft geen hoger beroep ingesteld tegen deze beschikking en heeft de dwangsom betaald.

Ook na deze beschikking heeft de Freistaat Bayern geen gevolg gegeven aan de bevelen die bij de beschikking van 27 februari 2017 waren gegeven. Integendeel, vertegenwoordigers van de Freistaat Bayern, onder wie de minister-president, hebben in het openbaar verklaard

22. Craeynest, punt 67

23. Craeynest, punt 63 .

24. Craeynest, punt 68 dat zij niet van plan waren de bovengenoemde verplichtingen om rijverboden op te leggen na te komen.

Nog weer nieuwe beschikkingen met dwangsommen volgden, maar een verzoek tot het opleggen van lijfsdwang jegens de minister van Milieu en Consumentenbescherming van de Freistaat Bayern, of anders de minister-president van die deelstaat, werd afgewezen. De Deutsche Umwelthilfe heeft tegen deze beschikking beroep ingesteld en in deze procedure heeft de rechter besloten de zaak te schorsen en te verwijzen naar het Hof van Justitie met een prejudiciële vraag.

De verwijzende rechter stelt daarbij dat hij niet verwacht dat de Freistaat Bayern gevolg zal geven aan de beschikking van 27 februari 2017 en de rijverboden zal vaststellen. Belangrijk daarbij is dat de betaling van een dwangsom voor de Freistaat Bayern namelijk niet gepaard gaat met vermogensverlies; bij de vereffening ervan wordt een bepaalde post op de begroting van de deelstaat met het door de rechter opgelegde bedrag gedebiteerd en wordt eenzelfde bedrag bij de centrale kas van de deelstaat als ontvangst geboekt.

Nakoming van de vastgestelde verplichtingen en rechterlijke beslissingen door middel van lijfsdwang tegen leden van de regering, de minister van Milieu en Consumentenbescherming van de deelstaat Beieren of de minister-president van die deelstaat stuit echter op grondwettelijke beperkingen en kan daarom niet op basis van Duits nationaal recht worden opgelegd. De rechter vraagt zich echter af of het Unierecht een andere beoordeling van deze situatie vereist, en stelt daarom samengevat de volgende vraag: Moeten de bepalingen van EU-recht die zien op doeltreffende uitvoering en rechtsbescherming van Europeesrechtelijke verplichtingen (art. 4 lid 3 Verdrag betreffende de Europese Unie (VEU), art. 197 lid 1 VWEU, art. 47 Handvest van de grondrechten van de Europese Unie, art. 9 lid 4 Verdrag van Aarhus en art. 19 lid 1 VEU) zo worden uitgelegd dat een Duitse rechter het recht - en zo nodig de plicht - heeft te bevelen dat functionarissen van een Duitse deelstaat worden gegijzeld teneinde de deelstaat te dwingen te voldoen aan zijn verplichting om een luchtkwaliteitsplan in de zin van artikel 23 Richtlijn 2008/50/EG te maken wanneer deze deelstaat definitief is veroordeeld, en de dreiging met en de oplegging van hogere dwangsommen dan tot nu toe het geval was geen noemenswaardig effect hebben of waarschijnlijk zullen hebben?

\section{Oordeel van het Hof van Justitie in Deutsche} Umwelthilfe

Het Hof van Justitie merkt allereerst op dat de vraag of lijfsdwang kan worden opgelegd wegens niet nakoming van EU-recht behoort tot de procedurele autonomie van een lidstaat maar dat de uitoefening hiervan conform vaste rechtspraak is gebonden an het gelijkwaardigheidsbeginsel en het effectiviteitsbeginsel. ${ }^{25}$ In de tweede plaats wijst het Hof van Justitie op het beginsel van effectieve rechterlijke bescherming zoals dat ook is neer- 
gelegd in artikel 47 eerste alinea Handvest, en specifiek voor het milieurecht in artikel 9 lid 4 Verdrag van Aarhus. ${ }^{26}$ Dat recht op effectieve rechtsbescherming zou denkbeeldig zijn indien het in de rechtsorde van een lidstaat mogelijk zou zijn dat een definitieve en bindende rechterlijke beslissing zonder uitwerking blijft ten nadele van een partij. ${ }^{27}$

Het Hof van Justitie verwijst daarbij eveneens naar de rechtspraak van het Europees Hof voor de Rechten van de Mens (EHRM) over artikel 6 lid 1 Europees Verdrag tot bescherming van de rechten van de mens en de fundamentele vrijheden (EVRM) waaruit blijkt dat als een overheidsorgaan zich niet voegt naar een definitieve en uitvoerbare rechterlijke beslissing deze bepaling elk nuttig effect wordt ontnomen. ${ }^{28}$

Daarbij benadrukt het Hof van Justitie ook hier dat het recht op een doeltreffende voorziening in rechte des te belangrijker is omdat nalaten de door Richtlijn 2008/50/EG vereiste maatregelen te nemen gevaar kan opleveren voor de gezondheid van personen. ${ }^{29}$ De nationale rechter moet derhalve een uitleg geven aan het nationale recht die zo veel mogelijk in overeenstemming is met de doelstellingen in artikel 9 lid 3 en 4 Verdrag van Aarhus. ${ }^{30}$ Dit betekent dat de rechter zal moeten onderzoeken of het nationale recht doeltreffende dwangmiddelen biedt die hij toe kan passen om te waarborgen dat overheidsorganen een in kracht van gewijsde gegaan vonnis ten uitvoer leggen, zoals hoge, kort na elkaar opgelegde dwangsommen die niet in laatste instantie terugvloeien in de begroting waaruit zij zijn betaald.

De verwijzende rechter heeft echter aangegeven dat hij hier niet in kan slagen, tenzij het Unierecht hem machtigt of zelfs verplicht om constitutionele gronden terzijde te schuiven die de rechter beletten om lijfsdwang toe te passen jegens functionarissen die openbaar gezag uitoefenen. Volgens het beginsel van voorrang dient iedere nationale bepaling die strijdig is met een bepaling van het Unierecht met rechtstreekse werking buiten toepassing te worden laten. ${ }^{31}$

Het beginsel van effectieve rechtsbescherming is volgens het Hof van Justitie echter niet absoluut en moet wel afgewogen worden tegen een beperking van het recht op vrijheid, dat door artikel 6 Handvest wordt gewaarborgd en dat in het geding komt bij een dwangmiddel als lijfsdwang. ${ }^{32}$ Ten eerste dient er in het nationale recht een rechtsgrond te zijn voor oplegging van

26. Deutsche Umwelthilfe, punt 34; zie ook HvJ 29 juli 2019, zaak C-556/17, ECLI:EU:C:2019:626 (Torubarov), punt 69.

27. Deutsche Umwelthilfe, punt 57. Zie ook HvJ 30 juni 2016, zaak C-205/15, ECLI:EU:C:2016:499 (Toma en Biroul Executorului Judecătoresc Horațiu-Vasile Cruduleci), punt 43.

28. Deutsche Umwelthilfe, punt 37; zie EHRM 19 maart 1997, appl.nr 18357/91, ECLI:CE:ECHR:1997:0319JUD001835791 (Hornsby/ Griekenland), punt 41 en 45

29. Deutsche Umwelthilfe, punt 38.

30. Deutsche Umwelthilfe, punt 39. Zie ook HvJ 8 maart 2011, zaak C-240/09, ECLI:EU:C:2011:125 (Lesoochranárske zoskupenie), punt 50 en 51 .

31. Deutsche Umwelthilfe, punt 42. Zie ook HvJ 9 maart 1978, zaak C-106/77, ECLI:EU:C:1978:49 (Simmenthal), punt 21.

32. Deutsche Umwelthilfe, punt 44. het dwangmiddel lijfsdwang. ${ }^{33}$ Ten tweede moet deze wet op grond waarvan iemand door een rechter zijn vrijheid kan worden ontnomen in het kader van artikel 52 lid 1 Handvest, voldoende toegankelijk en nauwkeurig zijn en de toepassing ervan moet voldoende voorzienbaar zijn, om willekeur uit te sluiten. ${ }^{34}$ Deze voorwaarden gelden immers voor elk type vrijheidsbeneming en dienen door de nationale rechter te worden onderzocht. ${ }^{35}$ Lijfsdwang kan pas worden toegepast wanneer het nagestreefde doel met geen enkele andere, minder belastende maatregel kan worden bereikt, aangezien een dergelijk dwangmiddel vrijheidsbeneming meebrengt. ${ }^{36}$ Het Hof overweegt dan dat:

'enkel in het geval dat de verwijzende rechter (...) concludeert dat de beperking van het recht op vrijheid door de oplegging van lijfsdwang voldoet aan de voorwaarden die in dat verband in artikel 52 lid 1 Handvest worden gesteld, zou het recht van de Unie de toepassing van een dergelijke maatregel niet alleen toestaan, maar zelfs vereisen.' [cursivering auteur]. ${ }^{37}$

Het Hof van Justitie onderstreept daarbij dat de volle werking van het recht van de Unie en de doeltreffende bescherming van de rechten die particulieren daaraan ontlenen, daarnaast kunnen worden gewaarborgd door het beginsel van staatsaansprakelijkheid. Dit geldt immers voor alle gevallen van schending van het Unierecht door een lidstaat, ongeacht de overheidsinstantie die zich aan die schending schuldig heeft gemaakt. ${ }^{38}$

\section{Commentaar}

Beide arresten versterken de rechtsbescherming en handhaving - twee kanten van dezelfde medaille - van milieurechten. De arresten zijn daarmee niet alleen relevant voor het afdwingen van 'een recht op schone lucht' maar hebben ook implicaties voor andere gebieden in het milieurecht, zoals biodiversiteit, klimaat en waterkwaliteit waarvoor bijvoorbeeld Europese grenswaarden zijn vastgesteld. ${ }^{39}$ Als in deze beleidsterreinen de overheid systematisch verzuimt EU-normen na te komen zal de nationale rechter op basis van het arrest Deutsche Umwelthilfe de op grond van het nationale recht tot zijn beschikking staande dwangmiddelen moeten toepassen

33. Deutsche Umwelthilfe, punt 46

34. Zie ook EHRM 21 oktober 2013, appl.nr. 42750/09, ECLI:CE:ECHR: 2013:1021JUD004275009 (Del Río Prada/Spanje); HvJ 15 maart 2017, zaak C-528/15, ECLI:EU:C:2017:213 (Al Chodor), punt 38 en 40.

35. Deutsche Umwelthilfe, punt 47.

36. Zie ook conclusie A-G H. Saugmandsgaard ØE 14 november 2019, zaak C-752/18, ECLI:EU:C:2019:972 (Deutsche Umwelthilfe), punt 86

37. Deutsche Umwelthilfe, punt 52.

38. Deutsche Umwelthilfe, punt 54 en 55. Zie ook HvJ 5 maart 1996, gevoegde zaken C-46/93 en C-48/93, ECLI:EU:C:1996:79 (Brasserie du pêcheur en Factortame), punt 20, 39 en 52; HvJ 28 juli 2016, zaak C-168/15, ECLI:EU:C:2016:602, (Tomášová), punt 18.

39. Zie over het recht op schone lucht U. Taddei, 'A Right to Clean Air in EU Law? Using Litigation to Progress from Procedural to Substantive Environmental Rights', Environmental Law Review 2016, nr. 3. 
om de overheid te dwingen om te handelen in overeenstemming met EU-recht - dit zal tevens een afschrikkende werking hebben. Juist in het milieurecht waar implementatie, toezicht en handhaving suboptimaal zijn (denk aan de slepende kwestie rondom de stikstofdepositie) is dit van belang.

De ontwikkeling van 'een recht op een schone lucht' is al kenbaar in eerdere gestage lijn in de jurisprudentie. Al in de jaren negentig heeft het Hof van Justitie vastgesteld dat overschrijding van luchtkwaliteitsnormen zo nauw verbonden is met menselijke gezondheid dat individuen hieraan rechten konden ontlenen die inroepbaar zijn bij de nationale rechter. ${ }^{40}$ In latere rechtspraak over de huidige Richtlijn 2008/50/EG heeft het Hof van Justitie meerdere keren bevestigd dat de grenswaarden in de richtlijn voldoende duidelijke en onvoorwaardelijke normen bevatten die burgers en ngo's in staat moeten stellen bij de nationale rechter plannen af te dwingen om de luchtkwaliteit te verbeteren. ${ }^{41}$ Deze plannen (die openbaar zijn) moeten een tijdsplan en gedetailleerde maatregelen bevatten over hoe de luchtkwaliteit binnen een zo een kort mogelijk tijdsbestek zal worden verbeterd.

De belangrijkste aanvulling die het Hof van Justitie in het Craeynest-arrest geeft, is dat ook het beoordelen van de luchtkwaliteit door de nationale rechter gecontroleerd moet kunnen worden. Het bepalen van de plaats van een bemonsteringspunt brengt een ingewikkelde wetenschappelijke beoordeling met zich mee: eerst moet worden beslist met welke methoden adequate gegevens worden verkregen die de basis vormen voor de locatiekeuze, en vervolgens moeten die gegevens worden geëvalueerd teneinde een locatie te bepalen. Ondanks de complexiteit hiervan oordeelde het Hof van Justitie dat dit onderworpen is aan rechterlijke toetsing. Ook dit kan van belang zijn voor andere terreinen binnen het milieurecht waar besluiten gebaseerd zijn op technische milieubeoordelingen.

\section{De intensiteit van de rechterlijke toetsing}

De interessantste observaties betreffende de intensiteit van de rechterlijke toetsing komen uit de pen van advocaat-generaal Kokott. ${ }^{42} \mathrm{Zij}$ verwijst eerst naar de toetsingsmaatstaven die de Unierechters toepassen wanneer zij maatregelen van de instellingen beoordelen. ${ }^{43} \mathrm{Bij}$ ingewikkelde wetenschappelijke of technische beoordelingen blijft rechterlijke toetsing beperkt tot de vraag of de autoriteiten bij de uitoefening van deze bevoegdheid de grenzen van hun beoordelingsbevoegdheid niet klaar-

40. HvJ 30 mei 1991, zaak C-361/88, ECLI:EU:C:1991:224 (Commissie/ Duitsland, TA-Luft Sulphur) en HvJ 30 mei 1991, zaak C-59/89, ECLI:EU:C:1991:225 (Commissie/Duitsland, TA-Luft Lead).

41. Zaken Janecek en ClientEarth.

42. Conclusie A-G J. Kokott 28 februari 2019, zaak C-723/17, ECLI:EU:C: 2019:168 (Craeynest)

43. Conclusie A-G, Craeynest, punt 42 blijkelijk hebben overschreden. Maar zij voegt eraan toe dat deze beoordelingsvrijheid in bepaalde gevallen intensiever getoetst kan worden, 'met name in het geval van verregaande inbreuken op fundamentele rechten'. ${ }^{44}$ Dit hangt af van een aantal factoren, waaronder met name het betrokken domein, de aard van het door het Handvest gewaarborgde recht dat aan de orde is, alsook de aard, de ernst en het doel van de inmenging. ${ }^{45}$

Interessant is dat zij de bepalingen van Richtlijn 2008/50/EG inzake de luchtkwaliteit interpreteert als een concretisering van het fundamentele recht op leven ex artikel 2 lid 1 Handvest, artikel 3 lid 3 VEU, artikel 37 Handvest en artikel 191 lid 2 VWEU (vereiste hoge niveau van milieubescherming). ${ }^{46}$ Hiermee wordt het recht op een schoon milieu vatbaar voor rechterlijke toetsing, hetgeen de gang naar de rechter verder opent voor particulieren en ngo's. ${ }^{47}$ Het Hof van Justitie verwijst naar de overweging van de advocaat-generaal waarin zij stelt dat de bepalingen inzake de luchtkwaliteit een concretisering zijn van de beschermingsverplichtingen van de Unie die voortvloeien uit het fundamentele recht op leven ex artikel 2 lid 1 Handvest en het volgens artikel 3 lid 3 VEU, artikel 37 Handvest en artikel 191 lid 2 VWEU vereiste hoge niveau van milieubescherming, maar gaat hier zelf niet verder op in. ${ }^{48}$ In Deutsche Ummelthilfe worden de handhaving van Richtlijn 2008/50/EG en het specifieke belang daarvan wel expliciet door het Hof van Justitie in het licht geplaatst van fundamentele rechten uit het Handvest en het Verdrag van Aarhus.

De doelstelling van Richtlijn 2008/50/EG om ter bescherming van het leven en de gezondheid van de bewoners zorg te dragen voor een adequate luchtkwaliteit, beperkt de beoordelingsvrijheid van de bevoegde instanties bij de ingewikkelde beoordeling waarop de situering van de bemonsteringspunten moet worden gebaseerd. Zij moeten bij twijfel een strategie kiezen die het risico tot een minimum beperkt dat overschrijdingen van grenswaarden niet worden vastgesteld. ${ }^{49}$

Het Hof van Justitie sluit zich aan bij de advocaat-generaal vanwege de 'cruciale rol' die de bemonsteringspunten spelen bij de doeltreffendheid van Richtlijn 2008/50/EG.${ }^{50}$ Daarom vervolgt het Hof van Justitie:

44. Conclusie A-G, Craeynest, punt 43

45. Conclusie A-G, Craeynest, punt 47 en 53 verwijzend naar HvJ 8 april 2014, gevoegde zaken C-293/12 en C-594/12, ECLI:EU:C:2014:238 (Digital Rights Ireland e.a.), punt 48.

46. Conclusie A-G, Craeynest, punt 53. A-G Kokott trekt de parallel tussen maatregelen die de effectieve toepassing van Richtlijn 2008/50/EG kunnen belemmeren en de ernstige inbreuk op fundamentele rechten op grond waarvan het Hof de regelingen inzake het bewaren van telecommunicatiedata aan een streng toezicht heeft onderworpen.

47. Ook de Nederlandse rechter heeft eerder luchtkwaliteit in het licht van de fundamentele rechten uit art. 2 en 8 EVRM besproken met verwijzing naar de jurisprudentie uit Straatsburg. Zie bijvoorbeeld. Rb. Den Haag 27 december 2017, AB 2018/115, m.nt. Van der Veen \& Backes, O\&A 2018/27, m.nt. Schutgens. In deze zaak werd overigens geen schending van het EVRM vastgesteld.

48. Craeynest, punt 33.

49. Conclusie A-G, Craeynest, punt 55

50. Craeynest, punt 47 
'Ook al vergt de keuze van de plaatsing van de bemonsteringspunten ingewikkelde technische beoordelingen, de beleidsvrijheid waarover de bevoegde nationale autoriteiten beschikken, wordt bijgevolg begrensd door de finaliteit en de doelstellingen die met de toepasselijke regels worden nagestreefd.'

Hierdoor kunnen niet alleen de verplichtingen uit de richtlijn op basis van de gegevens van overheidsinstanties worden afgedwongen maar kunnen ook deze gegevens (en daarmee de beoordeling) als zodanig worden betwist. Vooral op het gebied van luchtkwaliteit levert dat mogelijkheden op voor burgers omdat het door de snelle ontwikkeling van technologie relatief eenvoudig is de luchtkwaliteit vast te stellen. Dit is dan ook een trend te noemen door heel Europa heen, onder de noemer van Citizen Science-projecten. ${ }^{51}$ In een recente Belgische zaak heeft de rechter het belang van Citizen Science-data bevestigd: regionale overheden kunnen niet meer volstaan met het doorgeven van officiële gegevens maar dienen eveneens data betreffende luchtkwaliteit uit Citizen monitoring die in handen zijn gekomen van regionale overheden naar de Europese Commissie te sturen. ${ }^{52}$

Ook in Nederland is inmiddels in samenwerking met de overheid een burgerwetenschapsproject over luchtkwaliteit gestart. Hiertoe is het Schone Lucht Akkoord gesloten tussen Rijk, provincies en gemeenten. Onderdeel van het Akkoord is het betrekken van inwoners door middel van burgerwetenschap. Data kunnen gedeeld worden via het Samen Meten dataportaal, 'waardoor het RIVM Rijksinstituut voor Volksgezondheid en Milieu de kwaliteit van de data kan beoordelen en waar mogelijk verbeteren met behulp van metingen uit het luchtmeetnet en rekenmodellen'.53 Overigens waarschuwt de webpagina over het zelf meten van luchtkwaliteit dat 'de sensoren [die gebruikt kunnen worden door burgers] geen data [opleveren] waarmee je naar de rechter kunt'. Op basis van jurisprudentie van het Hof van Justitie valt over deze bewering inmiddels te twisten. Hieruit blijkt immers dat de grenswaarden uit artikel 13 een resultaatverplichting zijn. Indien die grenswaarden worden overschreden dient er een luchtkwaliteitsplan te worden opgesteld. Hoewel de lidstaat bij het invullen hiervan beleidsvrijheid heeft, is deze begrensd en vatbaar voor rechterlijk toezicht. ${ }^{54}$ In Craeynest voegde het Hof van Justitie hier immers aan toe dat 'de daadwerkelijke luchtverontreiniging [dient] te worden bepaald waaraan de bevolking of een deel daarvan wordt

51. Een bekend voorbeeld van de potentie van dit soort projecten is het eveneens Belgische 'curieuzeneuzenproject' waarin in 201820.000 inwoners van Vlaanderen participeerden, hetgeen resulteerde in een gerechtelijk bevel.

52. Rb. Brussel (vz.) 10 oktober 2018 (10de kamer), Tijdschrift voor Milieu en Recht 2018, p. 724-729, m.nt. A. Carette.

53. Zie het 'Samen Meten'-project van het RIVM: www.samenmetenaan luchtkwaliteit.nl.

54. Zie HvJ 5 april 2017, zaak C-488/15, ECLI:EU:C:2017:267 (Commissie/ Bulgarije), punt 112-114. Zie ook L. Krämer, '480.000 Dead per Year are Enough: The CJEU Opens a New Way to Better Enforce Air Quality Laws', Journal of European Environmental and Planning Law 2018, nr. 1, p. 111-121; Misonne 2020, p. 8 blootgesteld (...)'. Bijgevolg is het voldoende dat een grenswaarde op één enkel bemonsteringspunt wordt overschreden opdat de verplichting ontstaat tot vaststelling van een luchtkwaliteitsplan overeenkomstig artikel 23 lid 1 Richtlijn 2008/50/EG. ${ }^{55}$

\section{Procedurele autonomie}

Beide arresten worden geplaatst in het leerstuk van de procedurele autonomie. ${ }^{56}$ Dit houdt in dat procesregels zoals de gedwongen tenuitvoerlegging een zaak van interne rechtsorde zijn. Deze regels moeten wel aan twee voorwaarden voldoen, namelijk het gelijkwaardigheidsbeginsel en het doeltreffendheidsbeginsel. ${ }^{57}$

In het arrest Deutsche Ummelthilfe gaat het Hof van Justitie op dit laatste beginsel vervolgens uitvoerig in vanuit het recht op effectieve rechtsbescherming van artikel 47 Handvest en de rechtspraak van het EHRM met betrekking tot artikel 6 lid 1 EVRM. Hieruit blijkt dat indien een overheidsorgaan zich niet voegt naar een definitieve en uitvoerbare rechterlijke beslissing aan deze bepaling elk nuttig effect wordt ontnomen. ${ }^{58}$ Voor het Hof van Justitie weegt daarbij in het bijzonder dat de gezondheid van mensen in het geding is alsmede artikel 9 lid 3 en 4 Verdrag van Aarhus. ${ }^{59}$

Er dient dan wel in het nationale recht een voldoende toegankelijke en nauwkeurige rechtsgrond te zijn voor oplegging van een dergelijk dwangmiddel, en deze moet worden getoetst aan het evenredigheidsbeginsel en de eis van voorzienbaarheid zoals is neergelegd in artikel 6 lid 1 EVRM en artikel 52 lid 1 Handvest. ${ }^{60}$ Is echter aan deze voorwaarden voldaan dan wordt de bevoegdheid tot het opleggen van een maatregel die het recht op vrijheid beperkt (bijvoorbeeld lijfsdwang) een verplichting. Dit kan grote gevolgen hebben omdat de nationale rechter - indien deze sanctie ter beschikking staat - zal moeten toetsen en motiveren of deze toegepast dient te worden. In Nederland geven artikel 585 e.v. Wetboek van Burgerlijke Rechtsvordering ( $\mathrm{Rv}$ ) hiertoe een mogelijkheid maar, zoals al is opgemerkt door Barkhuijsen, het zal niet zo'n vaart lopen. ${ }^{61} \mathrm{Er}$ is immers het minder ingrijpende maar doeltreffende middel van verschillende en oplopende dwangsommen voorhanden dat volgens het Hof van Justitie moet worden toegepast, terwijl die dwangsommen bovendien niet in de staatskas verdwijnen maar aan de tegenpartij toekomen indien verbeurd. ${ }^{62}$

55. Craeynest, punt 67

56. HvJ 13 januari 2004, zaak C-453/00, ECLI:EU:C:2004:17 (Kühne \& Heitz).

57. Zie ook HvJ 26 juni 2019, zaak C-407/18, ECLI:EU:C:2019:537 (Addiko Bank), punt 46 .

58. EHRM 19 maart 1997, appl.nr. 18357/91, (Hornsby/Griekenland), punt 41 en 45.

59. Zie ook zaak Lesoochranárske zoskupenie, punt 50 en 51.

60. Deutsche Umwelthilfe, punt 46.

61. T. Barkhuysen, 'Lijfsdwang tegen autoriteiten die weigeren milieumaatregelen te nemen' NJB 2020/123, afl. 2.

62. Art. 611c Rv. 
Het Hof van Justitie wijst er ten slotte op dat staatsaansprakelijkheid eveneens een mogelijkheid biedt om aan het doeltreffendheidsbeginsel te voldoen zoals al sinds Francovich is bevestigd. ${ }^{63}$ Dat beginsel geldt volgens het Hof van Justitie immers 'voor alle gevallen van schending van het Unierecht door een lidstaat'. ${ }^{64}$ Bescherming van individuele rechten is hier het middel om het doel van effet utile te bereiken - hetgeen juist in milieuzaken van belang is. ${ }^{65}$ Advocaat-generaal Saugmandsgaard Øe noemt slechts de mogelijkheid van een inbreukprocedure en gaat niet in op de mogelijkheid van staatsaansprakelijkheid. ${ }^{66}$ In de eerdere arresten Fanecek en ClientEarth ging het Hof van Justitie niet expliciet op de mogelijkheid van staatsaansprakelijkheid in. Daarin oordeelde het Hof van Justitie, zoals hierboven besproken, dat de nationale rechter op verzoek van betrokken particulieren, wanneer een staat zijn verplichtingen krachtens Richtlijn 2008/50/EG niet nakomt om een luchtkwaliteitsplan op te stellen, een bevel dient te geven om alle noodzakelijke maatregelen te treffen indien daarin naar nationaal recht is voorzien.

\section{Conclusie}

De twee besproken arresten breiden de rechtsbescherming en handhavingsmogelijkheden voor particulieren en ngo's op het gebied van het milieurecht verder uit. In het Craeynest-arrest ging het om de plaatsing van meetapparatuur voor het beoordelen en monitoren van de luchtkwaliteit. Het Hof van Justitie oordeelde dat particulieren of ngo's die rechtstreeks getroffen worden door de overschrijding van de in de richtlijn gestelde grenswaarden een vordering bij de nationale rechter kunnen instellen, om te onderzoeken of de meetpunten op de juiste plaats zijn neergezet. Door deze interpretatie is het niet alleen mogelijk om de overheid aan te zetten tot het maken van luchtkwaliteitsplannen maar kan er ook gecontroleerd worden hoe de luchtkwaliteit wordt gemeten en beoordeeld. Hiermee opent het Hof van Justitie de mogelijkheid voor rechterlijk toezicht van complexe wetenschappelijke beoordelingen die veelal aan milieurechtelijke besluiten ten grondslag liggen hetgeen ook voor andere milieuzaken implicaties heeft.

In Deutsche Ummelthilfe oordeelde het Hof van Justitie dat het aan de nationale rechter is om lijfsdwang toe te passen om het nuttig effect van Richtlijn 2008/50/EG te verzekeren mits daarvoor in het nationale recht een rechtsgrond bestaat die voldoende toegankelijk en nauwkeurig is en waarvan de toepassing voldoende voorzienbaar is. Is dat het geval, dan moet de nationale rechter wel de evenredigheid van het middel toetsen mede in het licht van het recht op vrijheid uit artikel 6 Handvest voordat hij de lijfsdwang oplegt. Indien echter aan deze voorwaarden is voldaan en de nationale rechter zijn afweging heeft gemaakt verplicht het EU-recht lijfsdwang toe te passen.

Luchtkwaliteit en het maken van luchtkwaliteitsplannen hebben een duidelijke impact op de gezondheid van de blootgestelde bevolking, wat de beleidsvrijheid van bevoegde autoriteiten beperkt. Uit de twee hier besproken zaken komt duidelijk naar voren dat ingeval fundamentele rechten betrokken zijn bij de uitvoering en handhaving van Europees milieurecht de rechterlijke toetsing intensiever dient te zijn dan de gebruikelijke marginale toetsing. Hoewel het 'recht op schone lucht' als zodanig (nog) niet expliciet is erkend laten deze twee zaken zien dat het Hof van Justitie wederom rechtsbescherming en handhaving ten aanzien van luchtkwaliteit zeer serieus neemt. Het wordt interessant om te zien of en hoe deze jurisprudentie navolging krijgt in andere zaken op het gebied van bijvoorbeeld biodiversiteit, klimaat en water.

63. Zie Brasserie du pêcheur en Factortame, punt 20, 39 en 52 en Tomášová, punt 18. In deze rechtspraak leunde het Hof van Justitie op het doeltreffendheidsbeginsel om staatsaansprakelijkheid vast te stellen.

64. Deutsche Umwelthilfe, punt 54.

65. In de literatuur wordt dit ook wel aangeduid als 'functional subjectivisation', zie P. Wennerås, EC Environmental Law in National and Community Courts, Oxford: Oxford University Press 2005. Een goed voorbeeld hiervan is de milieuzaak HvJ 7 januari 2004, zaak C-201/02, ECLI:EU:C: 2004:12 (Wells).

66. Conclusie A-G, Deutsche Umwelthilfe, punt 89. Overigens is de Commissie al een inbreukprocedure begonnen tegen Duitsland, zie zaak C-635/18 (Commissie/Duitsland). 